BULLETIN OF PNRPU. GEOLOGY. OIL \& GAS ENGINEERING \& MINING

ВЕСТНИК ПНИПУ. ГЕОЛОГИЯ. НЕФТЕГАЗОВОЕ И ГОРНОЕ ДЕЛО

ISSN 2224-9923

Volume / Toм 16 №1 2017

http://vestnik.pstu.ru/geo/

УДК 622.244 .49

Article / Статья

(C) PNRPU / ПНИПУ, 2017

\title{
ANALYSIS AND JUSTIFICATION OF SELECTION OF FLUIDS TO BE USED FOR WATER SHUT-OFF TREATMENT DURING WELL COMPLETION
}

\author{
M.V. Dvoynikov, M.V. Nutskova, V.N. Kuchin
}

Saint Petersburg Mining University (2 21 ${ }^{\text {st }}$ Line, Vasilevskii island, Saint Petersburg, 199106, Russian Federation)

\section{АНАЛИЗ И ОБОСНОВАНИЕ ВЫБОРА СОСТАВОВ ДЛЯ ОГРАНИЧЕНИЯ ВОДОПРИТОКОВ ПРИ ЗАКАНЧИВАНИИ СКВАЖИН}

\section{М.В. Двойников, М.В. Нуцкова, В.Н. Кучин}

Санкт-Петербургский горный университет (199106, Россия, г. Санкт-Петербург, 21-я линия Васильевского острова, 2)

Received / Получена: 14.02.2017. Accepted / Принята: 02.03.2017. Published / Опубликована: 31.03.2017

\section{Key words:}

well drilling, challenges, water inflow, production formation, isolation, formation blockage, gas-liquid mixtures, foams, viscoelastic mixtures, abnormally low reservoir pressures, well completion, laboratory study, penetration, rheology, density.
Ключевые слова:

бурение скважин, осложнения, водопритоки, продуктивный пласт, изоляция, блокирование пласта, газожидкостные смеси, пены, вязкоупругие составы, пониженные пластовые давления, заканчивание скважин, лабораторные исследования, фильтрация, реология, плотность.

\begin{abstract}
The aim of the work is to increase efficiency of well completion under conditions of water inflow by use of viscoelastic gas-liquid mixtures to shut-off permeable formations.

At present, there is an increase in rates of drilling of wells in abnormal conditions, such as abnormal formation pressure (both low and high), unstable rocks, rocks of high hardness, permafrost etc. The quality of well construction in such conditions influences subsequent development and operation of the field greatly. Aquifer isolation is an extremely important issue due to the fact that from them water breaks through in production wells which has a significant impact on quality of fluid produced.

The main solution for water breakthrough challenge is formation isolation, which is performed by use of various plugging material. At present, there are many mixtures that limit water inflows such as fast-setting plugging materials, gel-cement mixtures, polymeric swelling nets, latexes, synthetic resins, viscoelastic mixtures, materials for selective isolation etc. Under conditions of abnormally low reservoir pressures, it is important to consider density when selecting drilling fluids and plugging materials. Therefore, it is recommended to use screens based on viscoelastic three-phase stabilized gas-liquid mixtures for temporary blockage of permeable aquifer. With use of such mixtures liquid penetration flow rate is significantly reduced compared to other viscoelastic systems, which makes it possible to increase reliability of temporary isolation of aquifers.

The paper presents an analysis of domestic and foreign experience of blocking permeable formations by different mixtures. Three-phase blocking mixtures are studied and requirements for them are generalized.
\end{abstract}

Целью работы является повышение эффективности заканчивания скважин в условиях водопритоков благодаря применению вязкоупругих газожидкостных смесей (ГЖС) для изоляции проницаемых горизонтов.

В настоящее время происходит увеличение темпов бурения скважин в осложненных условиях, таких как аномальные пластовые давления (как низкие, так и высокие), неустойчивые породы, породы высокой твердости, многолетнемерзлые породы и др. Качество строительства скважин в таких условиях во многом оказывает влияние на последующую разработку и эксплуатацию месторождения. Особенно остро стоит вопрос изоляции водоносных пластов, из которых происходят прорывы вод в добывающие скважины, оказывающие существенное влияние на качество добываемой продукции.

Основным решением проблемы прорыва вод является изоляция пластов, которая осуществляется применением различных тампонажных материалов. В настоящее время существует множество составов для ограничения водопритоков: быстросхватывающиеся тампонажные материалы, гельцементные растворы, полимерные набухающие сетки, латексы, синтетические смолы, вязкоупругие составы, материалы для селективной изоляции и др.

В условиях пониженных пластовых давлений при выборе буровых технологических жидкостей и тампонажных материалов важно учитывать плотность, поэтому для временного блокирования проницаемого водоносного горизонта целесообразным является применение экранов на основе вязкоупругих трехфазных стабилизированных ГЖС. При использовании таких составов значительно понижается скорость фильтрации жидкости по сравнению с другими вязкоупругими системами, что позволяет повысить надежность временной изоляции водоносных горизонтов.

В работе проведен анализ отечественного и зарубежного опыта блокирования проницаемых пластов различными составами, исследованы трехфазные блокирующие составы и обобщены требования к ним.

Mikhail V. Dvoynikov (Author ID in Scopus: 55945959000) - Doctor of technical sciences, Associate Professor, Professor at the Well Drilling Department (tel.: +007 8123288478 , e-mail: dvoinik72@gmail.com).

Mariia V. Nutskova (Author ID in Scopus: 57191341737) - PhD in technical sciences, Associate Professor at the Well Drilling Department (tel.: +007812328 84 78, e-mail: turitsyna_maria@mail.ru).

Viacheslav N. Kuchin - master student at the Well Drilling Department (tel.: +007812 32884 78, e-mail: cuchin.vya4eslaw2013@yandex.ru).

Двойников Михаил Владимирович - доктор технических наук, доцент, профессор кафедры бурения скважин (тел.: +007 8123288478 , e-mail: dvoinik72@gmail.com).

Нуцкова Мария Владимировна - кандидат технических наук, доцент кафедры бурения скважин (тел.: +007 81232884 78, e-mail: turitsyna_maria@mail.ru) Кучин Вячеслав Николаевич - магистрант кафедры бурения скважин (тел.: +007 81232884 78, e-mail: cuchin.vya4eslaw2013@yandex.ru). 


\section{Introduction}

An analysis of current state of development of oil and gas fields shows that significant amount of production wells is operated with more than $80 \%$ of water cut. Inactive wells represent more than 35 $\%$ and for some fields it is about $40-50 \%$ of total amount. At the same time, there are at least $15 \%$ of wells that have water cut sharply after they are put on production [1-4].

Breakthrough of water into production wells is often caused by presence of cross-flow due to poor quality of cement that can be caused by [5]:

- wrong density of cement slurry, when pressure in oil-bearing formation is higher than pressure created by slurry coloumn;

- poor quality adhesion at interfaces ("rockcement" and "cement-casing"), caused by poor quality removal of filter cake (especially during well flush by hydrocarbon-based solutions) and volume shrinkage of cement stone;

- premature thickening that cause decrease in hydrostatic pressure and, as a result, migration of fluid from the formation;

- low quality of cement slurry due to excessive water loss, low sedimentation resistance, high permeability, low strength and shrinkage of forming cement stone.

Today, there are several ways to overcome the challenge of qualitative isolation of water-bearing formations that are selective isolation of water inflows during repair and isolation works $[6,7]$, improvement of quality of well cementing [8-18] and temporary blockage of the reservoir [19-21].

In order to prevent channels to form by the migration of fluid from a well during thickening of cement the most expedient is to block permeable water-bearing formation for some time.

\section{Current state of the challenge}

Analysis of scientific and technical papers in the field of isolation of water inflows during oil production, as well as isolation of water-bearing formations during drilling and operation [3] shows trend of decrease in use of cement slurries during repair and isolation work. It is also found that a share of complex technologies and methods of selective isolation is increasing. Nevertheless, there is almost no attention paid to cross-flow prevention.
During construction of wells under conditions of low (including abnormaly low) pressures, well pressure plays a significant role. Therefore to block permeable intervals it is advisable to use low density mixtures such as three-phase foams. It was concluded in [22] that character of fluid flow in porous medium saturated with a three-phase foam nature of the solid phase has significant influence. According to that clays are recommended for isolation of non-oil-bearing formation and acid-soluble colmatants for oil-bearing ones. Parameters of mixtures that have been used for isolation of bottomhole formation zone are given in Tables 1 and 2 .

In some cases in order to block a formation hydrocarbon-based mixtures that include crump rubber are used. It leads to inconvertible blockage of a formation and permeability decrease because of crumb that do not dissolve and biodegrade during acid treatment. Thus, the mixture can be applied only in non-oil-bearing permeable formations to control loss circulation of flush fluid but only for drilling wells with flushing by hydrocarbon-based fluids.

If instead of crumb rubber calcium carbonate is used as filler material then mixtures can be used for temporary blockage of oil-bearing formation. Herewith such mixtures can be easily removed during acid treatment after perforation.

Foam mixtures (Table 2), designed to shut-in wells in abnormally low reservoir pressures, can be successfully applied to temporarily blockage of bottomhole zone and restriction of water inflows into the well.

Stable three-phase foams, which serve as a flow screen, are the most efficient. Due to the solid phase that is added to foam, stability of a foam increase, structural and mechanical properties improve and penetration intensity decreases. Presence of bentonite as a solid phase can lead to inconvertible colmatation of a permeable formation.

On the one hand, presence of chalk as filler and a solid phase to block temporary formation pores increase blockage abilities, on the other hand, complicate put-on production because a formation has to be unblocked. In order to unblock oilbearing formation from chalk during acid treatment its natural permeability is deformated due to interaction between the acid, minerals and formation water. 
Mixtures that block formation bottome hole zone

\begin{tabular}{|c|c|c|c|}
\hline Patent of RF & Composition & Parameters & Features \\
\hline No. 484300 [23] & $\begin{array}{l}\text { A mixture of condensate and sulfite- } \\
\text { alcohol spent wash (SASW) in a ratio of } \\
\text { 3:1.The water solution of SASW is } 38 \% \\
(25-50) \text {. Rubber crumb }(0.2-0.5 \%)\end{array}$ & $\begin{array}{c}\text { Density }-0.9-0.95 \mathrm{~g} / \mathrm{cm}^{3} \text {. } \\
\text { SSS }-80 \mathrm{~Pa} \cdot \mathrm{s}\end{array}$ & High static shear stress \\
\hline No. 2255209 [24] & $\begin{array}{c}\text { Hydrocarbon base (41-72). } \\
\text { Acyclic acid (6-14). } \\
\text { Caustic soda (4-13). } \\
\text { Mineral filler } \\
\end{array}$ & $\begin{array}{c}\text { Emulson density - } \\
1.02 \mathrm{~g} / \mathrm{cm}^{3}\end{array}$ & $\begin{array}{l}\text { Insufficiently high efficiency of } \\
\text { application in the fields with high } \\
\text { permeability formation }\end{array}$ \\
\hline No. 2196164 [25] & $\begin{array}{c}\text { Gas condensate }(5-75 \%) \text {. } \\
\text { SASW, concentration } 38 \%(25-50 \%) \text {. } \\
\text { Rubber crumb }(0.25-0.5 \%)\end{array}$ & $\begin{array}{c}\text { Density }-1030 \mathrm{~kg} / \mathrm{m}^{3}, \\
\text { viscosity }-42 \mathrm{~s} \\
\mathrm{SSS}_{1 / 10}-2 / 3 \mathrm{dPa} \\
\mathrm{DSS}-37.5 \mathrm{dPa} \\
\text { Plastic viscosity }- \\
129.5 \mathrm{mPa} \cdot \mathrm{s} \\
\end{array}$ & $\begin{array}{l}\text { Inconvercible blokage } \\
\text { of pore space of oil-bearing } \\
\text { formation }\end{array}$ \\
\hline No. 2309177 [26] & $\begin{array}{c}\text { CMC (1.5-2.0\%). } \\
\text { Magnesium chloride }(12-18 \%) \\
\text { Sodium hydroxide }(10-16 \%) \\
\text { Water - the rest. } \\
\text { In addition over } 100 \% \text { : } \\
\text { microspheres }(25-40 \%) \text {; chalk }(3-5 \%)\end{array}$ & $\begin{array}{c}\text { Density }-1300 \mathrm{~kg} / \mathrm{m}^{3} \\
\text { viscosity }-60 \mathrm{~s} \\
\text { penetration }-6 \mathrm{~cm}^{3} \\
\text { stability }-10 \mathrm{~min}\end{array}$ & $\begin{array}{l}\text { Ensuring blockage of bottomhole } \\
\text { formation zone of high permeability } \\
\text { ("super reservoirs") and cracks }\end{array}$ \\
\hline
\end{tabular}

Table 2

Foam mixtures designed to block a formation and limit water inflows

\begin{tabular}{|c|c|c|}
\hline Patent of RF & Composition & Features \\
\hline No. 1175951 [27] & $\begin{array}{c}\text { Lignin }(8.0-15.0) . \\
\text { Alkali }(0.3-5.0) . \\
\text { CMC }(0.2-0.6) \\
\text { Surfactant }(0.01-0.15) \\
\text { Petroleum product }(1.0-5.0) \text {. } \\
\text { Ethylenediamine }(0.05-1.5) \text {. } \\
\text { Water - the rest }\end{array}$ & $\begin{array}{l}\text { Instability of a system, weak ability to block, } \\
\text { negligible decrease in permeability of reservoirs after } \\
\text { workover }\end{array}$ \\
\hline No. 1208192 [28] & $\begin{array}{c}\text { Sulfonol or OP-10 (1-3). } \\
\text { Bentonite }(1-3) \\
\text { PAA }(0.5-0.7) \\
\text { CSASW-4 (5-8). } \\
\text { Fresh water - the rest }\end{array}$ & $\begin{array}{l}\text { Instability of a system, weak ability to block, } \\
\text { decrease in permeability of reservoirs after workover, } \\
\text { significant time expendetures to put a well on } \\
\text { production }\end{array}$ \\
\hline No. 2183735 [29] & $\begin{array}{c}\text { Surfactant }(0.5) . \\
\text { Potassium chloride }(5.0) \text {. } \\
\text { Hydroxyethyl carboxymethyl starch (3.0-4.0). } \\
\text { Condensed SASW }(0.5-1.0) \text {. } \\
\text { Chalk (3.0). } \\
\text { Water - the rest }\end{array}$ & $\begin{array}{l}\text { Insufficient well killing. } \\
\text { Formation of foam with low multiplicity }\end{array}$ \\
\hline No. 2187533 [30] & $\begin{array}{c}\text { Foaming agent }(0.8-1.8) \\
\text { Modified starch }(5.0-7.0) \\
\text { Sulfacell }(0.18-0.3) \\
\text { Chalk technical }(3.0-4.0) \\
\text { Alumino chloride }(1.1-1.4) \\
\text { Calcined soda }(0.6-0.8) \\
\text { Fresh water - the rest }\end{array}$ & Insufficient well killing \\
\hline
\end{tabular}

The main requirements for blocking mixtures are high viscosity, wide limits of regulation of structural, mechanical and rheological properties, low penetration value, preservation of reservoir properties and operating reservoir parameters (with a probability of penetration into oil-bearing formation), availible components, a simple technology of preparation in field conditions, ensuring work safety.
To block high permeability zones it is necessary to use a colmatant whose dimensions depend on formation pore size. The most suitable for this purpose is calcium carbonate of coarse fraction or microspheres (glass, aluminosilicate or ceramic).

General requirements for mixtures for temporary formation isolation under conditions of low pressures are as follows: 
1. A blocking mixture should be chemically inert to rocks, compatible with formation fluids and should avoid inconvertible reservoir pore blockage by solid particles.

2. The filtrate of blocking mixture must have an inhibitory effect on clay particles, preventing their swelling at any $\mathrm{pH}$ value of formation water.

3. The mixture should have thixotropic properties, in particular little resistance when moving in drill pipes and annulus and large when moving in permeable rocks.

4. Blocking mixture liquid must have low corrosive effect on downhole equipment. The rate of corrosion of steel should not exceed $0.10-0.12 \mathrm{~mm} / \mathrm{g}$.

5. Blocking mixture for isolation should be thermostable at high temperatures and frostresistant in winter conditions.

6. Blocking liquid must not be combustible, explosive and non-toxic.

7. Blocking mixture must be technological in preparation and use.

8. Technological properties of liquid for blocking must be regulated.

9. In fields with presence of hydrogen sulphide, mixtures must have a neutralizer of hydrogen sulphide.

Thus, development of a composition for temporary isolation of permeable water-bearing formation, which minimizes fluid penetration in a system "well-reservoir" and contamination of bottomhole formation zone, as well as a method of its removal from oil-bearing formation after jobs for subsequent shut-in and production, is an extremely important goal. An obtained result needs comprehensive study.

\section{Development of gas-liquid blocking liquid}

In order to put well on production effectively in conditions of low pressures and preserve reservoir properties to ensure temporary isolation it is needed to use gas-liquid blocking liquid with following parameters:

- density - less than $1000 \mathrm{~kg} / \mathrm{m}^{3}$;

- fluid penetration - no more than $5 \mathrm{~cm}^{3} / 30 \mathrm{~min}$;

- mud cake thickness $-0.5-1.0 \mathrm{~mm}$;

- hydrogen index $(\mathrm{pH})-7-8$;

- efficient viscosity - at least $65 \mathrm{mPa} \cdot \mathrm{s}$;

- dynamic shear stress (at surface/ bottomehole) - 400-1000/150-700 dPa;

- static shear stress $(1 \mathrm{~min} / 10 \mathrm{~min})$ - at least $15 / 15 \mathrm{dPa}$.
An oil-bearing formation can be characterized by high temperatures up to $90-100{ }^{\circ} \mathrm{C}$. So, it is reccomended to use heat-resistant gas-liquid blocking liquids that retain their properties during the entire time of liquid being in a well.

Thus, development of thermostable blocking liquids that have mentioned properties is a high priority issue.

A solution should include components that are as follows:

- polymer (biopolymer) to form a structure of gas-liquid blocking mixture;

- regulator of $\mathrm{pH}$;

- bactericide (in case starch reagents and biopolymers used);

- viscosity regulator;

- flow properties regulator;

- colmatant (to increase stability);

- additional components.

At the first stage, drilling muds are selected for density and fluid penetration matching. Studied solutions are given in Table 3.

Table 3

Composition of studied solutions, $\%$

\begin{tabular}{|l|c|c|c|c|c|c|c|c|}
\hline \multirow{2}{*}{\multicolumn{1}{|c|}{ Reagent }} & \multicolumn{7}{|c|}{ Solution } \\
\cline { 2 - 10 } & 1 & 2 & 3 & 4 & 5 & 6 & 7 & 8 \\
\hline Biopolymer & 2.6 & 1.5 & 1.5 & 0.5 & 0.3 & 0.3 & 0.4 & 0.3 \\
\hline Surfactants & 0.1 & 0.1 & 0.1 & 0.1 & 0.0 & 0.1 & 0.1 & 0.08 \\
\hline Colmatant & 2.0 & 2.0 & 2.0 & 1.0 & 1,0 & 1.0 & 0.8 & 0.8 \\
\hline PH regulator & 0.06 & 0.06 & 0.06 & 0.06 & 0.0 & 0.06 & 0.06 & 0.06 \\
\hline
\end{tabular}

In addition, stability was measured and multiplicity of the foam obtained was calculated. Results of experimental studies are presented in Table 4.

Table 4

Results of experimental studies

\begin{tabular}{|c|c|c|c|c|c|c|c|c|}
\hline \multirow{2}{*}{ Parameter } & \multicolumn{8}{|c|}{ Solution } \\
\hline & 1 & 2 & 3 & 4 & 5 & 6 & 7 & 8 \\
\hline Density, $\mathrm{kg} / \mathrm{m}^{3}$ & 920 & 840 & 780 & 800 & 820 & 800 & 810 & 800 \\
\hline Conditional viscosity, $\mathrm{s}$ & \multicolumn{4}{|c|}{ Non-flowing } & 45 & 55 & 150 & 99 \\
\hline Multiplicity of foam & 1.44 & 1.5 & 1.68 & 1.64 & 1.6 & 1.64 & 1.5 & 1.7 \\
\hline \multicolumn{9}{|l|}{ Dynamic viscosity, cP: } \\
\hline $3 \mathrm{rpm}$ & & & & & 1300 & 1367 & 1500 & 1100 \\
\hline $6 \mathrm{rpm}$ & & & & & 783 & 800 & 850 & 650 \\
\hline $100 \mathrm{rpm}$ & & & & & 114 & 112 & 96 & 83 \\
\hline $200 \mathrm{rpm}$ & & & & & 70 & 68 & 59 & 51 \\
\hline $300 \mathrm{rpm}$ & & & & & 50 & 50 & 46 & 37 \\
\hline $600 \mathrm{rpm}$ & & & & & 31 & 31 & 26 & 24 \\
\hline $\mathrm{pH}$ & 7.8 & 7.8 & 7.6 & 7.5 & 7.3 & 7.8 & 7.6 & 7.5 \\
\hline Stability, $\mathrm{kg} / \mathrm{m}^{3}$ & 0 & 0 & 0 & 0 & 150 & 200 & 0 & 170 \\
\hline Penetration, $\mathrm{cm}^{3} / 30 \mathrm{~min}$ & 0 & 0 & 0 & 0 & & & 8.8 & \\
\hline
\end{tabular}


The first four solutions showed high stability (there was no liquid escape from foam during 7 days) high values of resistance, good indexes of stability and fluid penetration, but they do not flow. Therefore, determination of their rheology was imposible. So, they were considered as inexpedient. Dynamic viscosities at different shear rates were measured for compositions 5-8. In general, dynamic viscosities are close to each other for all the solutions, but only $7^{\text {th }}$ solution has acceptable stability (no more than $20 \mathrm{~kg} / \mathrm{m}^{3}$ ). Compositions 5, 6 and 8 delaminated and showed insufficient stability values. There was a negative result for fluid penetration in $7^{\text {th }}$ sample. Therefore, in future research it is recommended to look over solutions that include following components: $0.4-0.5 \%$ of biopolymer, $0.05-0.1 \%$ of a surfactant and $0,8-1.0 \%$ of a colmatant. For control over rheology and penetration properties it is proposed to consider addition of low and high viscosity polyanionic cellulose in various concentrations to obtain optimal values.

Besides, it is necessary to evaluate thermal stability of compositions in the future and investigate technological and rheological properties after heating up to reservoir temperatures (for example, $90{ }^{\circ} \mathrm{C}$ ), and determine dependence of destruction of three-phase solution with increase in pressure up to reservoir.

\section{Findings and recommendations}

1. Temporary isolation is a necessary technical operation that is complicated by low reservoir pressure. Application of the products with low density, such as emulsions and foams, is important.

2. In case of temporary isolation, it is necessary to consider a possibility of penetration of blocking liquid into bottomhole zone of oil-bearing formation. As a result, it is necessary to exclude unsoluble in acids colmatant from composition of developing solutions.

3. Foams used to create a blocking screen must be stable from the moment of pumping until the end of cement thickening. Ground calcium carbonate is an effective filler to stabilize a solution. Calcium carbonate is dissolved easily during acid threatment.

4. The most successful blocking mixtures are liquids with a low dynamic shear stress at surface conditions and with a high pressure in bottomhole formation zone. That allows reducing the probability of penetration of liquid into an oilbearing formation and decreasing reservoir properties. High values of dynamic shear stress at surface conditions reduce performance factor and efficiency of a pump. Thus, forthcoming rheological studies should be focused on test of stated requirements and development of new solutions in case of negative result.

\section{References}

1. Zemtsov Iu.V., Timchuk A.S., Akinin D.V., Krainov M.V. Retrospektivnyi analiz metodov ogranicheniia vodopritokov, perspektivy dal'neishego razvitiia $\mathrm{v}$ Zapadnoi Sibiri [Retrospective analysis of methods applied for water inflows limiting, prospects of further development in the Western Siberia]. Neftepromyslovoe delo, 2014, no.4, pp.17-22.

2. Shamsutdinova M.Kh., Goitemirova S.U., Isaeva E.L., Bisieva Kh.Z., Sirieva Ia.N. Izoliatsiia vodopritokov v neftianye skvazhiny [Isolation of water inflows into oil wells]. Refleksiia, 2010, no.3, pp.50-54.

3. Magadova L.A., Silin M.A., Efimov N.N., Efimov M.N., Nigmatullin T.E., Khasanshin R.N. Opyt izoliatsii vodopritokov v dobyvaiushchikh neftianykh skvazhinakh $\mathrm{s}$ primeneniem selektivnykh materialov na uglevodorodnoi osnove [Experience in isolating water inflows in producing oil wells using selective hydrocarbon-based materials]. Territoriia Neftegaz, 2011, no.3, pp.68-73.

4. Bailey B. Water control. Oilfield Review, 2000, vol.12, iss.1, pp.30-51.

5. Piskunov A.I. Zakolonnye peretoki i analiz prichin ikh poiavleniia [Cross flows and analysis of causes of their occurrence]. Problemy razrabotki mestorozhdenii uglevodorodnykh i rudnykh poleznykh iskopaemykh, 2014, no.1, pp.141-144.

6. Krasnova E.I., Zotova O.P., Sivkov P.V. Primenenie selektivnykh materialov dlia ogranicheniia vodopritokov na mestorozhdeniiakh Zapadnoi Sibiri [The use of selective materials for limiting water inflows in fields of Western Siberia]. Akademicheskii zhurnal Zapadnoi Sibiri, 2013, vol.9, no.4 (47), pp.17-18.

7. Silin M.A., Rud' M.I., Davletshina L.F., Gubanov V.B., Magadov V.R., Fedorova L.A., Kyong F.Kh. Razrabotka bitumnoi emul'sii dlia primeneniia $\mathrm{v}$ tekhnologii selektivnoi izoliatsii vodopritokov [Development of bitumen emulsion for use in technology of selective isolation of water inflows]. Stroitel'stvo neftianykh $i$ gazovykh skvazhin na sushe i na more, 2010, no.11, pp.11-13.

8. Dvoinikov M.V. Razrabotka i issledovanie azotonapolnennykh tamponazhnykh sistem dlia krepleniia skvazhin [Development and study of nitrogen-filled plugging systems for well casing]. Abstract of Ph. D. thesis. Tiumen', 2005, 26 p.

9. Ismagilova E.R., Agzamov F.A. Razrabotka dobavok $\mathrm{v}$ «samozalechivaiushchiesia» tsementy dlia vosstanovleniia germetichnosti tsementnogo kol'ssa neftianykh i gazovykh 
skvazhin [Development of additives for self-healing cements to restore the cement stone integrity in oil and gas wells]. Burenie i neft', 2016, no.5, pp.36-41.

10. Nikolaev N.I., Liu Kh., Kozhevnikov E.V. Study of influence of polymer spacers on bond strength between cement and rock. Bulletin of Perm National Research Polytechnic University. Geology. Oil \& Gas Engineering \& Mining, 2016, vol.15, no.18, pp. 16-22. DOI: $10.15593 / 2224-9923 / 2016.18 .2$

11. Ovchinnikov P.V., Dvoinikov M.V., Ovchinnikov V.P., Frolov A.A., Bud'ko A.V., Prolubshchikov S.V., Arypov Sh.K. Kreplenie skvazhin $\mathrm{V}$ usloviiakh anomal'no nizkikh plastovykh davlenii [Well cementing in conditions of abnormally low reservoir pressures]. Izvestiia vysshikh uchebnykh zavedenii. Neft' i gaz, 2005, no.2, pp.28-34.

12. Piskunov A.I., Dvoinikov M.V. K voprosu tsementirovaniia skvazhin, proburennykh s ispol'zovaniem rastvorov na uglevodorodnoi osnove [To the question of well cementing drilled using hydrocarbon-based mixtures]. Estestvennye i tekhnicheskie nauki, 2016, no.6 (96), pp.60-62.

13. Davis R. Foam cementing program. Drilling, 1989, no.12, p.70.

14. Fujii K., Kondo W., Wataabe T. The hydration of portland cement immediately after mixing water. CementKlak-Gips, 1970, no.2.

15. Garvin T., Creel P. Foamed cement restores wellbore integrity in old wells. Oil \& Gas Journal, 1984, no.34, pp.125-126.

16. Ismailov A.A., Kabdulov S.Z., Tikebayev T.A. Analysis of the existing methods for elimination of cement slurry losses while well cementing. International Journal of Chemical Sciences, 2013, no.11(1), pp.150-158.

17. Montman R., Sutton D.L., Harms W.M. Foamed portland cements. Oil and Gas J, 1983, no.20, pp.219-232.

18. Rozieres S.D., Ferriere R. Foamed cements characterization under downhole conditions and I-bz impact on job design. SPE Prog. Eng., 1991, vol.3, pp.297-304. DOI: 10.2118/19935-PA

19. Gasumov R.A., Dubenko V.E., Minchenko Iu.S., Belous A.V., Seliukova V.N. Primenenie geleobrazuiushchikh sistem dlia vremennogo blokirovaniia gazovogo plasta pri tsementirovanii skvazhin s otkrytym zaboem [The use of gel-forming systems for temporary blocking of a gas reservoir during cementation of wells with an open bottom]. Vestnik Assotsiatsii burovykh podriadchikov, 2015, vol.1, no.2, pp.13-16.

20. Gasumov R.A., Kashapov M.A. Razrabotka penoobrazuiushchikh sostavov dlia bureniia i remonta skvazhin [Development of foam-forming compositions for well drilling and repairing]. Stroitel'stvo neftianykh $i$ gazovykh skvazhin na sushe i na more, 2009, no.12, pp.30-32.

21. Gasumov R.A., Ponomarenko M.N., Mosienko V.G. Kreplenie skvazhiny $\mathrm{s}$ vremennym blokirovaniem prizaboinoi zony produktivnogo plasta [Well cementing with temporary blocking of bottomhole zone of productive formation]. Stroitel'stvo neftianykh i gazovykh skvazhin na sushe i na more, 2007, no.8, pp.56-58.

22. Tagirov K.M., Nifantov V.I. Burenie skvazhin i vskrytie neftegazovykh plastov na depressii [Well drilling and underbalance perforation of oil and gas reservoirs]. Moscow, Nedra-Biznestsentr, 2003, 160 p.

23. Akopian N.R., Klimenko Z.K., Shmel'kov V.E. Emul'siia dlia glusheniia skvazhin [Emulsion for well killing]. Patent 484300 Rossiiskaia Federatsiia no.1323284, 1975.

24. Riabokon' S.A., Gertsena N.K., Gorlova Z.A. et al. Sposob glusheniia skvazhiny [Method of well killing]. Patent 2255209 Rossiiskaia Federatsiia no.2004100762/03, 2004.

25. Galian D.A., Komarova N.M., Chadina N.P., Glichev A.Iu. Emul'sionnyi rastvor [Emulsion mixture]. Patent 2196164 Rossiiskaia Federatsiia no. 2000131467/03, 2003.

26. Obidnov V.B., Kustyshev A.V., Mazanov S.V. et al. Sostav dlia blokirovaniia prizaboinoi zony plasta gazovykh skvazhin [Mixture for blocking bottomhole formation zone of gas wells]. Patent 2309177 Rossiiskaia Federatsiia no. 2006116076/03, 2007.

27. Ukhanov R.F., Kuksov A.K., Sheintsvit L.I. et al. Penoobrazuiushchii sostav dlia glusheniia skvazhin [Foaming mixture for well killing]. Patent 1175951 Rossiiskaia Federatsiia no.3696861, 1985.

28. Amiian V.A., Kiseleva G.S., Romashova M.M. et al. Zhidkost' dlia glusheniia skvazhin [Liquid for well killing]. Patent 1208192 Rossiiskaia Federatsiia no. 3769506, 1986.

29. Krylov G.V., Shtol' V.F., Kashkarov N.G. et al. Zhidkost' dlia glusheniia skvazhin [Liquid for well killing]. Patent 2183735 Rossiiskaia Federatsiia no.2000111805/03, 2002.

30. Gafarov N.A., Glichev A.Iu., Goronovich V.S. et al. Penoobrazuiushchii sostav [Foaming mixture]. Patent 2187533 Rossiiskaia Federatsiia no.2000131992/03, 2002.

\section{Библиографический список}

1. Ретроспективный анализ методов ограничения водопритоков, перспективы дальнейшего развития в Западной Сибири / Ю.В. Земцов, А.С. Тимчук, Д.В. Акинин, М.В. Крайнов // Нефтепромысловое дело. 2014. - № 4. - С. 17-22.

2. Изоляция водопритоков в нефтяные скважины / М.Х. Шамсутдинова, С.У. Гойтемирова, Э.Л. Исаева, Х.З. Бисиева, Я.Н. Сириева // Рефлексия. - 2010. - № 3. - С. 50-54.

3. Опыт изоляции водопритоков в добывающих нефтяных скважинах с применением селективных материалов на углеводородной основе / Л.А. Магадова, М.А. Силин, Н.Н. Ефимов, М.Н. Ефимов,
Т.Э. Нигматуллин, Р.Н. Хасаншин // Территория Нефтегаз. - 2011. - № 3. - С. 68-73.

4. Bailey B. Water control // Oilfield Review. - 2000. Vol. 12, iss. 1. - P. 30-51.

5. Пискунов А.И. Заколонные перетоки и анализ причин их появления // Проблемы разработки месторождений углеводородных и рудных полезных ископаемых. - 2014. - № 1. - С. 141-144.

6. Краснова Е.И., Зотова О.П., Сивков П.В. Применение селективных материалов для ограничения водопритоков на месторождениях Западной Сибири // Академический журнал Западной Сибири. - 2013. - Т. 9, № 4 (47). - С. 17-18. 
7. Разработка битумной эмульсии для применения в технологии селективной изоляции водопритоков / М.А. Силин, М.И. Рудь, Л.Ф. Давлетшина, В.Б. Губанов, В.Р. Магадов, Л.А. Федорова, Ф.Х. Кыонг // Строительство нефтяных и газовых скважин на суше и на море. - 2010. - № 11. - С. 11-13.

8. Двойников М.В. Разработка и исследование азотонаполненных тампонажных систем для крепления скважин: автореф. дис. ... канд. техн. наук. - Тюмень, 2005. $-26 \mathrm{c}$.

9. Исмагилова Э.Р., Агзамов Ф.А. Разработка добавок в «самозалечивающиеся» цементы для восстановления герметичности цементного кольца нефтяных и газовых скважин // Бурение и нефть. 2016. - № 5. - С. 36-41.

10. Николаев Н.И., Лю Х., Кожевников Е.В. Исследование влияния полимерных буферных жидкостей на прочность контакта цементного камня с породой // Вестник Пермского национального исследовательского политехнического университета. Геология. Нефтегазовое и горное дело. - 2016. - Т. 15, № 18. - С. 16-22. DOI: $10.15593 / 2224-9923 / 2016.18 .2$

11. Крепление скважин в условиях аномально низких пластовых давлений / П.В. Овчинников, М.В. Двойников, В.П. Овчинников, А.А. Фролов, А.В. Будько, С.В. Пролубщиков, Ш.К. Арыпов // Известия высших учебных заведений. Нефть и газ. - 2005. - № 2. - С. 28-34.

12. Пискунов А.И., Двойников М.В. К вопросу цементирования скважин, пробуренных с использованием растворов на углеводородной основе // Естественные и технические науки. - 2016. - № 6 (96). - С. 60-62.

13. Davis R. Foam cementing program // Drilling. 1989. - № 12. - P. 70.

14. Fujii K., Kondo W., Wataabe T. The hydration of portland cement immediately after mixing water // Cement-Klak-Gips. - 1970. - № 2.

15. Garvin T., Creel P. Foamed cement restores wellbore integrity in old wells // Oil \& Gas Journal. - 1984. № 34. - P. 125-126.

16. Ismailov A.A., Kabdulov S.Z., Tikebayev T.A. Analysis of the existing methods for elimination of cement slurry losses while well cementing // International Journal of Chemical Sciences. - 2013. - № 11 (1). - P. 150-158.

17. Montman R., Sutton D.L., Harms W.M. Foamed portland cements // Oil and Gas J. - 1983. - № 20. - P. 219-232.

18. Rozieres S.D., Ferriere R. Foamed cements characterization under downhole conditions and I-bz impact on job design // SPE Prog. Eng. - 1991. - Vol. 3. - P. 297-304. DOI: $10.2118 / 19935-\mathrm{PA}$

19. Применение гелеобразующих систем для временного блокирования газового пласта при цементировании скважин с открытым забоем / Р.А. Гасумов, В.Е. Дубенко, Ю.С. Минченко, А.В. Белоус, В.Н. Селюкова // Вестник Ассоциации буровых подрядчиков. - 2015. T. 1, № 2. - C. 13-16.

20. Гасумов Р.А., Кашапов М.А. Разработка пенообразующих составов для бурения и ремонта скважин // Строительство нефтяных и газовых скважин на суше и на море. - 2009. - № 12. - С. 30-32.

21. Гасумов Р.А., Пономаренко М.Н., Мосиенко В.Г. Крепление скважины с временным блокированием призабойной зоны продуктивного пласта // Строительство нефтяных и газовых скважин на суше и на море. - 2007. № 8. - С. 56-58.

22. Тагиров К.М., Нифантов В.И. Бурение скважин и вскрытие нефтегазовых пластов на депрессии. - М.: Недра-Бизнесцентр, 2003. - 160 с.

23. Эмульсия для глушения скважин: пат. 484300 Рос. Федерация / Акопян Н.Р., Клименко 3.К., Шмельков В.Е. № 1323284; заявл. 15.04.1969; опубл. 15.09.1975.

24. Способ глушения скважины: пат. 2255209 Рос. Федерация / Рябоконь С.А., Герцена Н.К., Горлова 3.А. [и др.]. - № 2004100762/03; заявл. 08.01.2004; опубл. 08.01.2004.

25. Эмульсионный раствор: пат. 2196164 Рос. Федерация / Галян Д.А., Комарова Н.М., Чадина Н.П., Гличев А.Ю. - № 2000131467/03; заявл. 15.12.00; опубл. 10.01.03.

26. Состав для блокирования призабойной зоны пласта газовых скважин: пат. 2309177 Рос. Федерация / Обиднов В.Б., Кустышев А.В., Мазанов С.В. [и др.]. № 2006116076/03; заявл. 10.05.06; опубл. 27.10.2007.

27. Пенообразующий состав для глушения скважин: пат. 1175951 Рос. Федерация / Уханов Р.Ф., Куксов А.К., Шейнцвит Л.И. [и др.]. - № 3696861; заявл. 30.01.1984; опубл. 30.08.1985.

28. Жидкость для глушения скважин: пат. 1208192 Рос. Федерация / Амиян В.А., Киселева Г.С., Ромашова М.М. [и др.]. - № 3769506; заявл. 30.01.1984; опубл. 30.08.1986.

29. Жидкость для глушения скважин: пат. 2183735 / Крылов Г.В., Штоль В.Ф., Кашкаров Н.Г. [и др.]. № 2000111805/03; заявл. 11.05.2000; опубл. 20.05.2002.

30. Пенообразующий состав: пат. 2187533 / Гафаров Н.А., Гличев А.Ю., Горонович В.С. и др. № 2000131992/03; заявл. 21.12.2000; опубл. 20.08.2002.

Please cite this article in English as:

Dvoynikov M.V., Nutskova M.V., Kuchin V.N. Analysis and justification of selection of fluids to be used for water shut-off treatment during well completion. Bulletin of PNRPU. Geology. Oil \& Gas Engineering \& Mining, 2017, vol.16, no.1, pp.33-39. DOI: $10.15593 / 2224-9923 / 2017.1 .4$

Просьба ссылаться на эту статью в русскоязычных источниках следующим образом:

Двойников М.В., Нуцкова М.В., Кучин В.Н. Анализ и обоснование выбора составов для ограничения водопритоков при заканчивании скважин // Вестник Пермского национального исследовательского политехнического университета. Геология. Нефтегазовое и горное дело. - 2017. - Т.16, №1. - C.33-39. DOI: 10.15593/2224-9923/2017.1.4 